\title{
Humidification and perceived indoor air quality in the office environment
}

\author{
Leena M Reinikainen, Leena Aunela-Tapola, Jouni J K Jaakkola
}

\begin{abstract}
Objective-To evaluate the effect of humidification on the odour, acceptability, and stuffiness of indoor air.

Methods-In a six period cross over trial at the Pasila Office Center, Helsinki, the air of two wings of the building in turn were ventilated with air of $30 \%-40 \%$ humidity. A third wing served as a non-humidified control area. The quality of indoor air was assessed weekly by a panel containing 18 to 23 members. The intraindividual differences in the ratings for odour, stuffiness, and acceptability between humidified and non-humidified wings were used to assess the effect of humidification. The roles of sex, current smoking, and age as potential effect modifiers were assessed by comparing the mean intraindividual differences in ratings between the groups.

Results-Humidified air was found to be more odorous and stuffy (paired $t$ test $P=0.0001)$ and less acceptable than the non-humidified air (McNemar's test $P<0.001)$. The differences in odour and stuffiness between humidified and nonhumidified air were greater for women and for non-smokers, and greatest differences were in the youngest age group, and least in the oldest age group. The differences were not significant.

Conclusions-An untrained panel of 20 members is able to differentiate a slight malodour and stuffiness in indoor air. The results suggest that steam air humidification decreases the perceived air quality. This effect is strongest in women and young subjects.
\end{abstract}

(Occup Environ Med 1997;54:322-327)

Epidemiology Unit, Department of Public Health, University of Helsinki, Finland

L M Reinikainen J J K Jaakkola

Technical Reseach Centre of Finland L Aunela-Tapola

Laboratory of Heating, Ventilating and AirConditioning, Helsinki University of

Technology

L M Reinikainen

J J K Jaakkola

Correspondence to:

Dr L M Reinikainen

Environmental Epidemiology

Unit, Department of Public

Unit, Department of Pub
Health, University of
Helsinki, PO Box 41 ,

FIN-00014, Finland.

Accepted 11 December 1996 mucosae and the sensation of air dryness experienced by workers in the Pasila Office Center. ${ }^{12}$ On the other hand, the humidified air felt more stuffy than the non-humidified air. Not many experimental studies have been made on the effects of humidification on symptoms and perceived indoor air quality. In a Swedish experiment it was found that humidification decreased the sensation of dryness, symptoms of sick building syndrome, and also malodour. $^{3}$

The objective of this study was to evaluate the effect of humidification on the perception of odour, odour acceptability, and the stuffiness of indoor air.

\section{Methods}

BUILDING

The study was carried out at the Pasila Office Center in January and February 1989 in connection with a six period crossover humidification trial. The building consists of six symmetric wings with a total of 2150 clerical workers. The entire building has a mechanical ventilation system that supplies air through ducts into corridors in each wing. A more detailed description of the building and its ventilation system is included in the previous publication about the humidification trial.

Temperature and relative humidity were measured continuously in three rooms in each wing. Chemical and microbiological components were measured in the building, and meteorological data on the period of the study were obtained. These data are described in the previous publication. ${ }^{1}$

STUDY DESIGN AND OUTCOMES OF INTEREST Three wings of the building were used in this study. During the preceeding control period of one week, no humidification was used in the two experimental wings (A and B). During the first week of the experiment, after random selection, one of the experimental wings (A) was ventilated with air of $30 \%-40 \%$ humidity, whereas no humidification was used in the other wing (B). A third wing (C) served as a non-humidified control throughout the study. The relative humidity in the non-humidified wing was determined mainly by natural conditions. The operation of the humidification system was switched between wings at the weekend, and a similar crossover was carried out four more times. The panellists did not know which of the wings was being humidified. Once during the experiment the humidification was switched off by accident the day before the test. The results from this week were therefore excluded from the analysis of the overall effect of air humidification. 
Table 1 Characteristics of the study population in different one-week periods: control and six experimental periods

\begin{tabular}{|c|c|c|c|c|c|c|c|c|}
\hline Characteristic & $\begin{array}{l}\text { Control } \\
\text { period } \\
n(\%)\end{array}$ & $\begin{array}{l}\text { week } 1 \\
n(\%)\end{array}$ & $\begin{array}{l}\text { week } 2 \\
n(\%)\end{array}$ & $\begin{array}{l}\text { week } 3 \\
n(\%)\end{array}$ & $\begin{array}{l}\text { week } 4 \\
n(\%)\end{array}$ & $\begin{array}{l}\text { week } 5 \\
n(\%)\end{array}$ & $\begin{array}{l}\text { week } 6 \\
n(\%)\end{array}$ & $\begin{array}{l}\text { Total } \\
n(\%)\end{array}$ \\
\hline $\begin{array}{l}\text { Total } \\
\text { Sex: }\end{array}$ & 23 & 23 & 20 & 18 & 18 & 19 & 20 & 141 \\
\hline $\begin{array}{l}\text { Men } \\
\text { Women }\end{array}$ & $\begin{array}{r}15(65 \cdot 2) \\
8(34 \cdot 8)\end{array}$ & $\begin{array}{r}14(60 \cdot 9) \\
9(39 \cdot 1)\end{array}$ & $\begin{array}{r}11(55 \cdot 0) \\
9(45 \cdot 0)\end{array}$ & $\begin{array}{r}12(66 \cdot 7) \\
6(33 \cdot 3)\end{array}$ & $\begin{array}{r}11(61 \cdot 1) \\
7(38 \cdot 9)\end{array}$ & $\begin{array}{r}12(63 \cdot 2) \\
7(36 \cdot 8)\end{array}$ & $\begin{array}{r}15(75 \cdot 0) \\
5(25 \cdot 0)\end{array}$ & $\begin{array}{l}90(63 \cdot 8) \\
51(36 \cdot 2)\end{array}$ \\
\hline $\begin{array}{l}\text { Age: } \\
\quad<24 \\
25-34 \\
\geqslant 35\end{array}$ & $\begin{array}{r}7(30 \cdot 4) \\
11(47 \cdot 8) \\
5(21 \cdot 7)\end{array}$ & $\begin{array}{r}7(30 \cdot 4) \\
11(47 \cdot 8) \\
5(21 \cdot 7)\end{array}$ & $\begin{array}{l}6(30 \cdot 0) \\
9(45 \cdot 0) \\
5(25 \cdot 0)\end{array}$ & $\begin{array}{l}6(33 \cdot 3) \\
7(38 \cdot 9) \\
5(27 \cdot 8)\end{array}$ & $\begin{array}{l}6(33 \cdot 3) \\
6(33 \cdot 3) \\
6(33 \cdot 3)\end{array}$ & $\begin{array}{l}4(21 \cdot 1) \\
9(47 \cdot 4) \\
6(31 \cdot 6)\end{array}$ & $\begin{array}{l}5(25 \cdot 0) \\
9(45 \cdot 0) \\
6(30 \cdot 0)\end{array}$ & $\begin{array}{l}41(29 \cdot 1) \\
62(44 \cdot 0) \\
38(26 \cdot 9)\end{array}$ \\
\hline $\begin{array}{l}\text { Current smoking: } \\
\text { No } \\
\text { Yes }\end{array}$ & $\begin{array}{r}16(69 \cdot 6) \\
7(30 \cdot 4)\end{array}$ & $\begin{array}{r}17(73 \cdot 9) \\
6(26 \cdot 1)\end{array}$ & $\begin{array}{r}14(70 \cdot 0) \\
6(30 \cdot 0)\end{array}$ & $\begin{array}{r}13(72 \cdot 2) \\
5(27 \cdot 8)\end{array}$ & $\begin{array}{r}12(66 \cdot 7) \\
6(33 \cdot 3)\end{array}$ & $\begin{array}{r}12(63 \cdot 2) \\
7(36 \cdot 8)\end{array}$ & $\begin{array}{r}13(65 \cdot 0) \\
7(35 \cdot 0)\end{array}$ & $\begin{array}{l}97(68 \cdot 8) \\
44(31 \cdot 2)\end{array}$ \\
\hline
\end{tabular}

The quality of indoor air was assessed by untrained odour panels. The number of participants in the weekly panel varied from 18 to 23. The members of the panel were recruited through an advertisment at the Helsinki University of Technology. They were students and members of the staff of the University. The members of the panel varied weekly so that some of them were present every time, some others participated only once.

On Fridays of each week the participants of the panel were assigned randomly into three groups, each entered the wings of the building in a random sequence. The outcome of interest was perceived indoor air quality measured as ratings of odour, stuffiness, and the acceptability of odour. The panellists filled in a questionnaire about the quality of both outdoor and indoor air. They were asked to report on perceived intensity of odour (structured answers: $1=$ no odour, $2=$ weak odour, $3=$ moderate odour, $4=$ strong odour, $5=$ very strong odour, $6=$ intolerable odour), acceptability of the odour $(0=$ acceptable, $1=$ not acceptable), and stuffiness ( $1=$ very fresh, $2=$ fresh, $3=$ neutral, $4=$ slightly stuffy, $5=$ stuffy) outside and in two corridors in each wing. To avoid adaptation to odour, the panellists went outside between changing wings and corridors.

\section{Statistical methods}

The means of the outcome ratings were calculated for each week separately and for the humidified and non-humidified periods in the experimental wings.

In the statistical analysis, ratings for the outcome variables of every panellist were considered as paired observations in comparing the three pairs of wings ( $\mathrm{A} v \mathrm{~B}, \mathrm{~A} v \mathrm{C}$, and $\mathrm{B} v \mathrm{C}$ ), and the overall effect of humidification. The paired differences calculated from

Table 2 Temperature $(T)$ and relative humidity $(R H)$ in the study areas on the odour panel days

\begin{tabular}{|c|c|c|c|c|c|c|c|}
\hline \multirow[b]{3}{*}{ Period } & \multirow{3}{*}{$\begin{array}{l}\text { Humidified } \\
\text { wing }\end{array}$} & \multicolumn{4}{|c|}{ Experimental wings } & \multirow{2}{*}{\multicolumn{2}{|c|}{$\frac{\text { Control wing }}{\text { Wing } C}$}} \\
\hline & & \multicolumn{2}{|l|}{ Wing $A$} & \multicolumn{2}{|l|}{ Wing $B$} & & \\
\hline & & $T\left({ }^{\circ} \mathrm{C}\right)$ & $R H(\%)$ & $T\left({ }^{\circ} \mathrm{C}\right)$ & $R H(\%)$ & $T\left({ }^{\circ} \mathrm{C}\right)$ & $R H(\%)$ \\
\hline $\begin{array}{l}\text { Control } \\
1 \\
2 \\
3 \\
4 \\
5 \\
6\end{array}$ & $\begin{array}{l}\text { None } \\
\text { A } \\
\text { B } \\
\text { A } \\
\text { B } \\
\text { None } \\
\text { B }\end{array}$ & $\begin{array}{l}28 \cdot 0 \\
22 \cdot 0 \\
21 \cdot 8 \\
21 \cdot 8 \\
21 \cdot 5 \\
21 \cdot 8 \\
21 \cdot 5\end{array}$ & $\begin{array}{l}26 \cdot 3 \\
32 \cdot 1 \\
28 \cdot 3 \\
34 \cdot 6 \\
28 \cdot 3 \\
27 \cdot 1 \\
23 \cdot 7\end{array}$ & $\begin{array}{l}23 \cdot 0 \\
22 \cdot 5 \\
22 \cdot 5 \\
22 \cdot 5 \\
23 \cdot 5 \\
22 \cdot 3 \\
23 \cdot 0\end{array}$ & $\begin{array}{l}27 \cdot 0 \\
27 \cdot 4 \\
31 \cdot 7 \\
25 \cdot 2 \\
29 \cdot 1 \\
21 \cdot 8 \\
36 \cdot 5\end{array}$ & $\begin{array}{l}22 \cdot 3 \\
21 \cdot 8 \\
21 \cdot 8 \\
21 \cdot 8 \\
21 \cdot 7 \\
21 \cdot 7 \\
21 \cdot 5\end{array}$ & $\begin{array}{l}31 \cdot 1 \\
29 \cdot 5 \\
30 \cdot 1 \\
27 \cdot 5 \\
29 \cdot 1 \\
22 \cdot 7 \\
26 \cdot 6\end{array}$ \\
\hline
\end{tabular}

the ratings of the individual panellists were considered as independent observations in comparing the differences between wings and the humidified and non-humidified periods.

The significance of the intraindividual difference between the weekly mean ratings for odour and stuffiness in the two experimental wings, and between the experimental wing with no humidification and the control area was assessed by a two tailed paired $t$ test. The significance of the difference between the experimental and control wings in the proportion of subjects who found the indoor air odour acceptable was assessed by McNemar's test.

The relations between the odour and stuffiness of indoor air and the humidification were studied by comparing the mean intraindividual difference of the ratings during the humidified and non-humidified periods, and testing with the paired $t$ test to find if the mean intraindividual difference of the outcomes was different from zero. To assess the role of sex, current smoking, and age as potential modifiers of the effect of humidification, the mean intraindividual differences of the outcomes between men and women, non-smokers and smokers, and three age groups: $<25 ; 25$ to 34 ; and $\geqslant 35$ were calculated, and the significance of the differences was assessed in the linear regression that adjusted for other modifiers.

\section{Results}

PANELS AND EXPERIMENTAL CONDITIONS

Table 1 shows the characteristics of the weekly panels. Nine questionnaire forms were rejected because of incomplete information about either outdoor or indoor variables. The total number of accepted forms was 280 for wing A, 279 for wing B, and 276 for wing C.

The material used in the analysis of the overall effect of humidification consisted of 194 pairs of formulae. Of this population 70 $(36 \%)$ were women and $124(64 \%)$ men. There was no significant difference in the smoking habits of women and men. The age distribution was different. Forty per cent of the women and $25 \%$ of the men were in the youngest age group, and $29 \%$ of the women and $51 \%$ of the men were in the middle age group. Smoking habits were different in the age groups, so that non-smokers were almost equally distributed in the three groups, but over half of the smokers were in the middle 
Table 3 Means, 95\% CIs, and $P$ values of the indoor air odour ratings for the three wings, and intraindividual difference between the experimental areas $A$ and $B$ and between the non-humidified and control wings

\begin{tabular}{|c|c|c|c|c|c|c|c|}
\hline \multirow[b]{3}{*}{ Period } & \multirow{3}{*}{$\begin{array}{l}\text { Humidified } \\
\text { wing }\end{array}$} & \multicolumn{3}{|c|}{ Group means of the ratings } & & & \\
\hline & & \multicolumn{2}{|c|}{$\begin{array}{l}\text { Experimental } \\
\text { wings } A \text { and } B\end{array}$} & \multirow{2}{*}{$\begin{array}{l}\text { Control } \\
\text { wing } C \\
\bar{x}_{C}\end{array}$} & \multicolumn{3}{|c|}{ Intraindividual difference $\left(\bar{\Delta}_{A-B}\right)$ between experimental wings $(A-B)$} \\
\hline & & $\bar{x}_{t}$ & $\bar{x}_{B}$ & & $n_{l}$ & $\bar{\Delta}_{A B}(95 \% C I)$ & $P_{A B}$ \\
\hline $\begin{array}{l}\text { Control } \\
1 \\
2 \\
3 \\
4 \\
5 \\
6\end{array}$ & $\begin{array}{l}\text { None } \\
\text { A } \\
\text { B } \\
\text { A } \\
\text { B } \\
\text { None } \\
\text { B }\end{array}$ & $\begin{array}{l}2 \cdot 42 \\
2 \cdot 51 \\
2 \cdot 00 \\
2 \cdot 28 \\
1 \cdot 86 \\
1 \cdot 89 \\
1 \cdot 92\end{array}$ & $\begin{array}{l}2 \cdot 20 \\
2 \cdot 07 \\
2 \cdot 44 \\
1 \cdot 81 \\
2 \cdot 11 \\
2 \cdot 00 \\
2 \cdot 33\end{array}$ & $\begin{array}{l}2 \cdot 14 \\
2 \cdot 20 \\
1 \cdot 92 \\
2 \cdot 00 \\
1.91 \\
1 \cdot 92 \\
2 \cdot 08\end{array}$ & $\begin{array}{l}45 \\
45 \\
39 \\
36 \\
35 \\
38 \\
39\end{array}$ & $\begin{array}{l}0.22(-0.07 \text { to } 0.51) \\
0.44(0.21 \text { to } 0.68) \\
-0.44(-0.69 \text { to }-0.18) \\
0.47(0.16 \text { to } 0.79) \\
-0.26(-0.53 \text { to } 0.01) \\
-0.11(-0.35 \text { to } 0.14) \\
-0.41(-0.74 \text { to } 0.08)\end{array}$ & $\begin{array}{l}0 \cdot 14 \\
0 \cdot 001 \\
0 \cdot 002 \\
0 \cdot 006 \\
0 \cdot 71 \\
0 \cdot 40 \\
0 \cdot 019\end{array}$ \\
\hline
\end{tabular}

$P_{A B}=$ significance of the $t$ test between the intraindividual difference of perceived indoor odour in the wings $A$ and $B ; P_{A C}=$ significance of the $t$ test between the intraindividual difference of perceived indoor odour in the wings $A$ and $C ; P_{B C}=$ significance of the $t$ test between the intraindividual difference of perceived indoor odour in the wings $B$ and $C ; n_{1}=$ number of answers obtained in the comparison between the wing $A$ and $B ; n_{2}=$ number of answers obtained in the comparison between the wing $A$ or $B$ against $C ; \star^{\star} \bar{x}_{B}$ in the comparison $=2 \cdot 19 ; f^{-}{ }_{B}$ in the comparison $=2 \cdot 09$.

Table 4 Means, 95\% CIs, and P values of the ratings for indoor air stuffiness for the three wings, and intraindividual difference between the experimental areas $A$ and $B$ and between non-humidified and control wings.

\begin{tabular}{|c|c|c|c|c|c|c|c|}
\hline \multirow[b]{3}{*}{ Period } & \multirow{3}{*}{$\begin{array}{l}\text { Humidified } \\
\text { wing }\end{array}$} & \multicolumn{3}{|c|}{ Group means of the ratings } & & & \\
\hline & & \multicolumn{2}{|c|}{$\begin{array}{l}\text { Experimental } \\
\text { wings } A \text { and } B\end{array}$} & \multirow{2}{*}{$\begin{array}{l}\text { Control } \\
\text { wing } C \\
\bar{x}_{G}\end{array}$} & \multicolumn{3}{|c|}{ Intraindividual difference $\left(\bar{\Delta}_{A B}\right)$ between humidified and non-humidified $(A-B)$} \\
\hline & & $\bar{x}_{A}$ & $\overline{\mathrm{x}}_{B}$ & & $n_{l}$ & $\bar{\Delta}_{A B}(95 \% C I)$ & $P_{A B}$ \\
\hline Control & None & 3.51 & $3 \cdot 58$ & $3 \cdot 35$ & 45 & $-0.07(-0.33$ to 0.19$)$ & $0 \cdot 61$ \\
\hline 1 & & 3.64 & $3 \cdot 42$ & $3 \cdot 43$ & 45 & $0.22(-0.03$ to 0.48$)$ & $0 \cdot 13$ \\
\hline 2 & $\mathbf{B}$ & 3.33 & $3 \cdot 87$ & $3 \cdot 18$ & 39 & $-0.54(-0.81$ to -0.27$)$ & 0.0003 \\
\hline 3 & A & 3.67 & $3 \cdot 25$ & $3 \cdot 33$ & 36 & $0.42(0.14$ to 0.69$)$ & 0.005 \\
\hline 4 & B & $3 \cdot 22$ & $3 \cdot 71$ & $3 \cdot 25$ & 35 & $-0.49(-0.76$ to 0.21$)$ & 0.001 \\
\hline 5 & None & $3 \cdot 32$ & $3 \cdot 39$ & $3 \cdot 26$ & 38 & $-0.08(-0.33$ to 0.17$)$ & $0 \cdot 54$ \\
\hline 6 & B & $3 \cdot 33$ & $3 \cdot 87$ & $3 \cdot 17$ & 39 & $-0.54(-0.80$ to -0.28$)$ & 0.0002 \\
\hline
\end{tabular}

$\mathrm{P}_{\mathrm{AB}}=$ significance of the $t$ test between the intraindividual difference of perceived indoor air stuffiness in the wings A and B; $\mathrm{P}_{\mathrm{AC}}=$ significance of the $t$ test between the intraindividual difference of perceived indoor air stuffiness in the wings $A$ and $C ; P_{B C}=$ significance of the $t$ test between the intraindividual difference of perceived indoor air stuffiness in the wings $B$ and $C ; n_{1}=$ number of answers obtained in the comparison between the wing A and B; $n_{2}=$ number of answers obtained in the comparison between the wing $A$ or $B$ against $C ; \star^{\star} \bar{X}_{B}$ in the comparison $=3 \cdot 45$.

age group, the rest being equally distributed in the other groups.

The relative humidity in the non-humidified areas was $21 \%-31 \%$ and in the humidified areas $30 \%-35 \%$. Table 2 shows the means of the point measurements of temperature and relative humidity during the days of the experiment.

The panellists reported that outdoor air had mostly no or little odour $(95 \cdot 8 \%)$, and it was mostly very fresh, fresh, or neutral air $(96.9 \%)$, and its odour was acceptable $(97 \cdot 6 \%)$. There were no major changes in the outdoor air quality during the experiment. Outdoor air variables did not differ either between the three wings or during change over of corridors.

Indoor air was mostly reported to have no or little odour ( $21 \cdot 2 \%$ little and $51 \cdot 5 \%$ none), $23.2 \%$ rated the odour as being moderate, $3.7 \%$ strong, and $0.4 \%$ very strong. In $87.2 \%$ of the questionnaires odour was considered to be acceptable. Indoor air was not considered to be very fresh. In $6 \cdot 1 \%$ of the questionnaires the scoring was fresh, $50.9 \%$ neutral, $36.3 \%$ slightly stuffy, and $6.7 \%$ stuffy. The differences between wings $A, B$, and $C$ in the mean ratings for odour and stuffiness during the control week were not significant (analysis of variance: odour $P=0 \cdot 18$; stuffiness $P=$ $0 \cdot 23)$. There were no significant differences between any of the weekly means of the ratings during the experiment in the wing $C$ (analysis of covariance, controlling for sex, age, and current smoking: odour $\mathrm{P}=0.63$; stuffiness $P=0.69$ ).

Table 5 Acceptability of indoor air odour by period

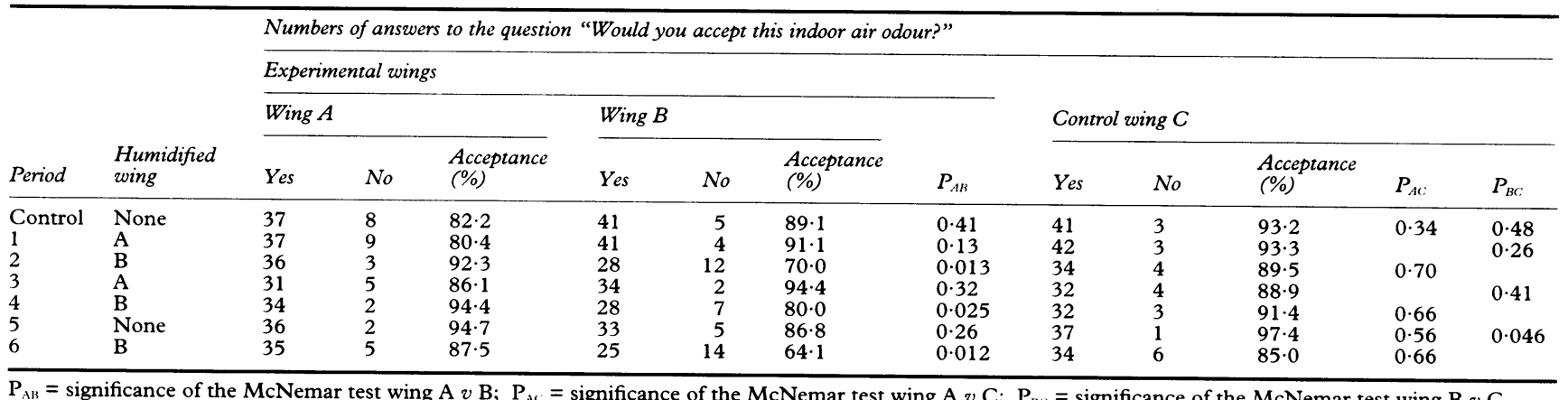


Table 3 continued

\begin{tabular}{llllll}
\multicolumn{7}{c}{$\begin{array}{l}\text { Intraindividual difference between non-humidified } \\
\text { experimental wing }(A \text { or } B) \text { and control wing }(C)\end{array}$} \\
\cline { 2 - 6 } Period & $n_{2}$ & $\bar{\Delta}_{A C}(95 \% C I)$ & $P_{A C}$ & $\bar{\Delta}_{B C}(95 \% C I)$ & $P_{B C}$ \\
\hline Control & 43 & $0.26(-0.04$ to 0.55$)$ & 0.09 & $0.05^{\star}(-0.24$ to 0.33$)$ & 0.75 \\
1 & 44 & & $-0.11+(-0.40$ to 0.17$)$ & 0.44 \\
2 & 37 & $0.08(-0.16$ to 0.33$)$ & 0.52 & $-0.19(-0.45$ to 0.06$)$ & 0.15 \\
3 & 36 & $-0.06(-0.31$ to 0.20$)$ & 0.66 & & $0.08(-0.17$ to 0.33$)$ \\
4 & 35 & $-0.03(-0.28$ to 0.23$)$ & 0.83 & 0.54 \\
5 & 38 & $-0.15(-0.44$ to 0.14$)$ & 0.32 & & \\
6 & 39 & -0 &
\end{tabular}

Table 4 continued

\begin{tabular}{llllll}
\multicolumn{7}{c}{$\begin{array}{l}\text { Intraindividual difference between non-humidified } \\
\text { experimental wing }(A \text { or } B) \text { and control wing }(C)\end{array}$} \\
\cline { 2 - 6 } Period & $n_{2}$ & $\bar{\Delta}_{A-C}(95 \% C I)$ & $P_{A C}$ & $\bar{\Delta}_{B C}(95 \% C I)$ & $P_{B C}$ \\
\hline Control & 43 & $0.16(-0.10$ to 0.42$)$ & 0.22 & $0.23(-0.07$ to 0.53$)$ & 0.13 \\
1 & 44 & & & $0.02^{\star}(-0.27$ to 0.31$)$ & 0.88 \\
2 & 37 & $0.19(-0.10$ to 0.48$)$ & 0.21 & $-0.08(-0.39$ to 0.22$)$ & 0.59 \\
3 & 36 & & & & \\
4 & 35 & $-0.03(-0.23$ to 0.18$)$ & 0.79 & $0.13(-0.10$ to 0.37$)$ & 0.28 \\
5 & 38 & $0.05(-0.16$ to 0.26$)$ & 0.62 & & \\
6 & 39 & $0.15(-0.07$ to 0.37$)$ & 0.18 & & \\
\hline
\end{tabular}

\section{EFFECT OF HUMIDIFICATION}

The panellists reported, on average, more odour in the indoor air during the humidified weeks. The intraindividual difference in assessment of odour intensity reached significance (paired $t$ test $\mathrm{P}<0.05$ ) during all but the fourth week of the experiment. The ratings for odour were similar between the nonhumidified experimental wing and the control wing (table 3 ).

Humidified air felt more stuffy than nonhumidified air. The difference in the means reached significance (paired $t$ test $\mathrm{P}<0.05$ ) during all but the first week of the experiment. The ratings for stuffiness between the nonhumidified experimental wing and the control wing were similar (table 4).

Table 5 shows weekly numbers of positive and negative answers to the question: "Would you find the odour of the indoor air acceptable, if there was as strong an odour in your working place as there is here?" The intraindividual difference within people in the acceptability between humidified and nonhumidified air was significant during the three experimental weeks when wing $\mathrm{B}$ was being humidified (McNemar test $\mathrm{P}<0 \cdot 05$ ). The overall acceptability of the non-humidified air was $90.6 \%$ and of the humidified air $76.4 \%$ (McNemar test $\mathrm{P}<0.001$ ).

The humidified air was perceived to be more odorous and stuffy than the non-humidified (paired $t$ test $P=0.0001$, table 6).

Women's ratings for odour were lower for both humidified and non-humidified air. But the adjusted intraindividual difference in women's ratings between humidified and nonhumidified periods was greater for both odour and stuffiness although only nearly significant for stuffiness (odour $P=0.68$, stuffiness $P=$ $0 \cdot 060$ ). So women experienced humidified air to be more odorous and stuffy than men (table 6).

During the non-humidified period there was no difference in the ratings for odour and stuffiness between current smokers and nonsmokers. Both groups reported more odour and stuffiness during the humidified period. The intraindividual difference in the ratings was greater but not significant among the nonsmokers than smokers (table 6).

The panellists in the age groups $<25$ and $\geqslant 35$ reported less odour and stuffiness in the non-humidified period than panellists in the age group 25 to 34 . The proportions in the absolute ratings were the same in the humidified period. The intraindividual difference in the ratings between non-humidified and humidified periods was greatest among the

Table 6 Determinants of perceived indoor air odour and stuffiness and differences in the effect of humidification by sex, smoking, and age

\begin{tabular}{|c|c|c|c|c|c|c|c|c|c|c|}
\hline \multirow[b]{3}{*}{ Derminant } & \multicolumn{5}{|c|}{ Odour } & \multicolumn{5}{|c|}{ Stuffiness } \\
\hline & \multicolumn{3}{|c|}{$\begin{array}{l}\text { Group means during non- } \\
\text { humidified and humidified period }\end{array}$} & \multicolumn{2}{|c|}{$\begin{array}{l}\text { Mean intraindividual } \\
\text { difference }\end{array}$} & \multicolumn{3}{|c|}{$\begin{array}{l}\text { Group means during non- } \\
\text { humidified and humidified period }\end{array}$} & \multicolumn{2}{|c|}{$\begin{array}{l}\text { Mean intraindividual } \\
\text { difference }\end{array}$} \\
\hline & $n$ & $\bar{x}_{0}$ & $\bar{x}_{1}$ & $\bar{\Delta}$ & $P \Delta$ & $n$ & $\bar{x}_{0}$ & $\bar{x}_{1}$ & $\bar{\Delta}$ & $P \Delta$ \\
\hline Humidification & 194 & 1.94 & $2 \cdot 35$ & $0 \cdot 41$ & $0.0001^{\star}$ & 194 & $3 \cdot 32$ & $3 \cdot 75$ & 0.43 & $0.0001^{\star}$ \\
\hline Sex: & & & & & & & & & & \\
\hline $\begin{array}{l}\text { Women } \\
\text { Men }\end{array}$ & 70 & 1.86 & $2 \cdot 29$ & 0.44 & & 70 & 3.41 & 3.99 & 0.58 & \\
\hline $\begin{array}{l}\text { Men } \\
\text { Current smoking: }\end{array}$ & 124 & 1.99 & $2 \cdot 37$ & 0.38 & $0.68 t$ & 124 & $3 \cdot 28$ & $3 \cdot 62$ & 0.34 & $0.060 \dagger$ \\
\hline $\begin{array}{l}\text { No } \\
\text { Yes }\end{array}$ & $\begin{array}{r}137 \\
57\end{array}$ & $\begin{array}{l}1.94 \\
1.95\end{array}$ & $\begin{array}{l}2 \cdot 39 \\
2 \cdot 24\end{array}$ & $\begin{array}{l}0.34 \\
0 \cdot 29\end{array}$ & $0 \cdot 26 \ddagger$ & $\begin{array}{r}137 \\
57\end{array}$ & $\begin{array}{l}3 \cdot 33 \\
3 \cdot 30\end{array}$ & $\begin{array}{l}3 \cdot 82 \\
3 \cdot 58\end{array}$ & $\begin{array}{l}0 \cdot 49 \\
0 \cdot 27\end{array}$ & $0 \cdot 10 \ddagger$ \\
\hline $\begin{array}{l}\text { Age: } \\
\quad<25 \\
25-34 \\
\geqslant 35\end{array}$ & $\begin{array}{l}59 \\
83 \\
52\end{array}$ & $\begin{array}{l}1 \cdot 83 \\
2 \cdot 18 \\
1 \cdot 70\end{array}$ & $\begin{array}{l}2 \cdot 28 \\
2 \cdot 57 \\
2 \cdot 06\end{array}$ & $\begin{array}{l}0.45 \\
0.40 \\
0.36\end{array}$ & $0.86 \rrbracket$ & $\begin{array}{l}59 \\
83 \\
52\end{array}$ & $\begin{array}{l}3.00 \\
3 \cdot 65 \\
3 \cdot 18\end{array}$ & $\begin{array}{l}3 \cdot 63 \\
4 \cdot 03 \\
3 \cdot 45\end{array}$ & $\begin{array}{l}0.63 \\
0 \cdot 39 \\
0 \cdot 27\end{array}$ & $0.066 \$$ \\
\hline
\end{tabular}

$\star \mathrm{P}=$ significance of the paired $t$ test with $\mathrm{H}_{0}$ : the mean of the intraindividual difference of the scores between humidified and non-humidified is equal to 0 . $+P=$ significance of the linear regression with $\mathrm{H}_{0}$ : the mean intraindividual difference in perceptions of odour and stuffiness is equal between men and women,

$\neq \mathrm{P}=$ significance of the linear regression with $\mathrm{H}_{0}$ : the mean intraindividual difference in perceptions of odour and stuffiness is equal between smokers and non$¥ \mathbf{P}=$ significance of the linear regressio

$\$ P=$ significance of the linear regression with $\mathrm{H}_{0}$ : the mean intraindividual difference in perceptions of odour and stuffiness is equal between the three age groups, controlling for sex and smoking.

controlling for sex and smoking. $\bar{x}_{0}=$ the mean of the score during non-humidified period, $\bar{x}_{1}=$ the mean of the score during humidified period, $\bar{\Delta}=$ meand
during humidified and non-humidified periods. Mean scores for men and women, smokers and non-smokers, and for different age groups are adjusted for potential confounders. 
youngest and least among the oldest age groups for both odour and stuffiness. The differences for stuffiness approached significance $(P=0.066$, table 6$)$.

\section{Discussion}

We used untrained panels of visitors to assess the intensity of odour and stuffiness of the indoor air and the acceptability of the odour in blinded controlled experiments in the office environment with and without humidification. The mean ratings of odour and stuffiness were consistently greater when the areas were humidified than when there was no humidification. The panellists also considered the odour of the humidified air less acceptable than that of the non-humidified air. These findings are in line with the results of the concurrent six period crossover trial, in which the occupants reported the air to be significantly more stuffy during the humidified than the non-humidified period. ${ }^{1}$ Humidification also slightly increased, non-significantly, the unpleasant odour perceived by the workers. At the same time humidification was found to alleviate the sensation of dryness as well as its symptoms of the eyes, skin, and respiratory tract. The effect of humidification on stuffiness perceived by the panellists was modified by both sex and age, so that the effect was stronger in women and younger panellists. The results of the panel and the epidemiological studies are not directly comparable, because the panellists were sniffing air in corridors where air is conducted from an air conditioning device, whereas the workers were evaluating air quality in their offices. ${ }^{12}$

\section{VALIDITY OF RESULTS}

The experimental design ensures the study's validity in several ways. The randomisation of the panel and intraindividual comparison of symptoms between humidified and nonhumidified conditions eliminated potential confounding due to personal characteristics. The sequence of the entry was also randomised and the participants were not told about the humidification, and thus the information from the different wings was comparable. The panellists went outside between visits to different areas to eliminate the effects of exposure in one wing being carried over into a subsequent wing. Also randomisation of the order of visiting the wings for each panel member would decrease the role of any carryover effect. The use of a non-humidified control area enabled the assessment of potential confounding by changes in the external conditions.

SYNTHESIS WITH PREVIOUS KNOWLEDGE The effects of humidification on the symptoms of the sick building syndrome and perceived indoor air quality were studied in a recent humidification experiment carried out in Swedish hospitals. ${ }^{3}$ The study design was a parallel four group experimental study with two humidified buildings and two non-humidified controls. In that experiment humidifica- tion seemed to decrease rather than increase the sensations of odour and stuffiness; the differences were not significant, which is contrary to both our panel study and the cross sectional trial. It is possible that there were some differences in the study populations or the buildings causing the humidified air to feel less odorous and stuffy, or possibly the longer period of humidification alleviating the symptoms of dryness made the indoor air more acceptable, which was interpreted as feelings of less odour and stuffiness. In a chamber study with a temperature range of $20-27^{\circ} \mathrm{C}$ and relative humidity of $20 \%$ to $>65 \%$, the air quality was judged to be unacceptable when the relative humidity exceeded $50 \%$, and the air was perceived to be less stuffy with decreasing temperature and humidity. ${ }^{4}$ These findings are in line with our results.

Humidification tended to raise the temperature in wing B which may be the cause for the humidified air being less acceptable than in wing A. In an odour panel study performed in office buildings in Denmark high temperature was found to be associated with odour intensity. ${ }^{5}$

Men reported the non-humidified air to be more odorous but less stuffy than women. On the other hand exposure to humidified air caused a greater rise in the sensations in women than men. In an olfactometric experiment with a population sample of 134 Swedish men and 130 women in the age groups 18-24, $25-50$, and $\geqslant 51$, studying the odour threshold of dimethyl monosulphide, Lindvall found that odour sensitivity was somewhat higher for women than men although the difference was not significant. ${ }^{6}$ It is possible that in our population men had a different scale in evaluating the quality of indoor air, but if we consider sniffing humidified air as exposure to a potential odorant the effect is similar to the finding of Lindvall.

In our study panellists in the age group 25-34 evaluated the indoor air odour and stuffiness to be stronger than did the younger and older panellists. The difference in the perceptions within individual people was greater for the younger and diminished in the older age groups. This finding is in line with Lindvall's. In his olfactometric experiment sensitivity of both sexes to odour was highest in the age group 18-24 and lowest in the age group $\geqslant 51 .{ }^{6}$

\section{Conclusions}

An untrained panel of 20 members is able to differentiate a slight malodour and stuffiness in indoor air. The results suggest that steam air humidification decreases the perceived indoor air quality. This may be due to changes in emission rates from the building materials and the air conditioning device, or sensation of odour, or both these factors, even though the measurements did not show any difference in the chemical composition between humidified and non-humidified air. The effect of humidification seems to be modified by sex and age so that the perceptions of women and younger 
panellists during humidification are stronger than those of men and older panellists.

This study was supported by The Finnish Work Environment Fund.

1 Reinikainen LM, Jaakkola JJK, Seppänen O. The effect of air humidification on symptoms and perceptions of indoor air quality in office workers: a six-period crossover trial. Arch Environ Health 1992;47:8-15.

2 Reinikainen LM, Jaakkola JJK, Heinonen OP. The effect of air humidification on different symptoms in office workers-an epidemiologic study. Environment
International 1991;17:243-50

3 Nordström K, Norbäck D, Akselsson R. Effect of air humidification on the sick building syndrome and perceived indoor air quality in hospitals: a four month longitudinal study. Occup Environ Med 1994;51:683-8.

4 Berglund LG, Cain WS. Perceived air quality and the thermal environment. LAQ 89, the human equation: health and comfort. San Diego: ASHRAE, 1989:93-9.

5 Zweers T, Skov P, Valbiørn O, Mølhave L. The effect of ventilation and air pollution on perceived indoor air quality in five town halls. Energy and Building 1990:14: ity in five

6 Lindvall $\mathrm{T}$. On sensory evaluation of odorous air pollutant intensities. Nordisk Hygienisk Tidskrift 1970;(suppl 2): 98-106.

\section{Correspondence and editorials}

Occupational and Environmental Medicine welcomes correspondence relating to any of the material appearing in the journal. Results from preliminary or small scale studies may also be published in the correspondence column if this seems appropriate. Letters should be not more than 500 words in length and contain a minimum of references. Tables and figures should be kept to an absolute minimum. Letters are accepted on the understanding that they may be subject to editorial revision and shortening.

The journal also publishes editorials which are normally specially commissioned. The Editor welcomes suggestions regarding suitable topics; those wishing to submit an editorial, however, should do so only after discussion with the Editor. 